\title{
KEANEKARAGAMAN DAN KELIMPAHAN MAKROFAUNA TANAH PADA TIGA TEGAKAN BERBEDA DI HUTAN PENDIDIKAN GUNUNG WALAT
}

\author{
The Diversity and Frequency of Soil Macrofauna on Three Different Trees at Educational Forest \\ of Gunung Walat
}

\section{Cahyo Wibowo ${ }^{1}$ dan Muhammad Fahmi Alby ${ }^{2}$}

(Diterima April 2017/Disetujui Februari 2020)

\begin{abstract}
Soil macrofauna is an important factor in studying the biological soil quality. The activity of soil macrofauna affects the soil properties and condition. The objective of this study was to identify the soil macrofauna and analyze the diversity, evenness, and richness index of soil macrofauna on some sites at educational forest of gunung Walat. The macrofauna was collected using hand sorting method on $40 x 40 \mathrm{~cm}$ plots in $10 \mathrm{~cm}$ depth of soil and $3-5 \mathrm{~cm}$ thick of forest litters at Agathis, Pinus, and Puspa trees. The identification result showed that a total 641 individuals were found under Agathis, Pinus, and Puspa trees. The Pinus trees showed the highest frequency of soil macrofauna (377 individu). The Agathis trees showed the highest value of diversity index, that was $H^{\prime}=2.38, D M g=4.12$, and $E=0.78$.
\end{abstract}

Keywords: abundance, diversity, soil macrofauna, hand sorting method, Gunung Walat

\section{PENDAHULUAN}

Makrofauna tanah merupakan salah satu faktor penting dalam mempelajari kualitas tanah secara biologis. Aktivitas yang dilakukan makrofauna di dalam tanah mempengaruhi sifat-sifat dan kondisi tanah. Organisme yang berada di dalam tanah membentuk ekosistem yang sanggup mengadakan perubahanperubahan besar di dalam tanah, terutama di lapisan atas (top soil), di mana terdapat akar tanaman dan perolehan bahan makanan yang mudah.

Ketersediaan energi dan hara yang bersumber dari aktivitas makrofauna tanah akan memberikan dampak positif terhadap kesuburan tanah. Aktivitas makrofauna tanah menghasilkan senyawa-senyawa organik yang baik untuk keseimbangan unsur hara dalam tanah serta berpengaruh positif terhadap sifat fisik tanah. Manfaat secara biologis dan fisik tersebut menjadikan keberadaan makrofauna tanah sangat penting untuk menilai kualitas tanah.

Keberadaan makrofauna dalam tanah sangat tergantung pada ketersediaan energi dan sumber makanan seperti bahan organik dan biomassa hidup yang seluruhnya berkaitan dengan aliran siklus karbon dalam tanah. Hutan Pendidikan Gunung Walat merupakan salah satu kawasan hutan yang terdiri atas berbagai macam tegakan. Informasi dan pengetahuan mengenai kelimpahan dan keanekaragaman fauna tanah merupakan salah satu bidang kajian yang perlu diketahui dalam

\footnotetext{
${ }^{1}$ Dosen Departemen Silvikultur, Fakultas Kehutanan Institut Pertanian Bogor

* Penulis korespondensi:

e-mail: cahyo_odum@yahoo.com

2 Mahasiswa Departemen Silvikultur, Fakultas Kehutanan Institut Pertanian Bogor
}

rangka pemantauan kondisi tanah di Hutan Pendidikan Gunung Walat. Penelitian ini bertujuan untuk mengidentifikasi makrofauna tanah yang terdapat pada berbagai tapak di Hutan Pendidikan Gunung Walat, serta menganalisis indeks keragaman, kelimpahan dan kekayaan jenis makrofauna tanah pada berbagai tapak di Hutan Pendidikan Gunung Walat.

\section{METODE PENELITIAN}

\section{Waktu dan Tempat}

Penelitian berlangsung dalam dua tahap, yaitu pengambilan data lapangan dan identifikasi makrofauna tanah. Pengambilan data dilakukan pada bulan FebruariMaret 2015. Pengambilan sampel makrofauna tanah dilakukan di tiga ekosistem (agathis, pinus, puspa) yang ada di Hutan Pendidikan Gunung Walat, Sukabumi. Identifikasi fauna tanah dilakukan antara lain di laboratorium Entomologi Hutan Departemen Silvikultur, Fakultas Kehutanan Institut Pertanian Bogor, Jawa Barat.

\section{Alat dan Bahan}

Alat yang digunakan dalam penelitian adalah sarung tangan, pinset, plastik transparan berukuran besar, kantong plastik ukuran $1 \mathrm{~kg}$, Global Positioning System (GPS), buku identifikasi, penggaris, termometer tanah, sarung tangan, tally sheet, $\mathrm{pH}$ meter, mikroskop digital, cangkul, kamera, pita ukur, label, tali rafia, densiometer. Bahan-bahan yang digunakan dalam penelitian ini berupa sampel makrofauna dan tanah. Bahan lain yang digunakan sebagai pendukung antara lain akuades, alkohol $70 \%$ dan 50\%, digunakan selama pengamatan di laboratorium dan lapang. 


\section{Jenis Data yang Dikumpulkan}

Data yang dikumpulkan selama penelitian ini berupa data primer dan sekunder. Data primer diperoleh melalui pengamatan langsung di plot penelitian, seperti pengambilan sampel makrofauna tanah, pengukuran suhu tanah dan kerapatan tajuk, serta ketebalan serasah. Data sekunder dihimpun berdasarkan informasi yang didapat dari pihak Hutan Pendidikan Gunung Walat melalui studi literatur dan wawancara selama penelitian berlangsung. Sumber literatur lain diperoleh dari buku, jurnal, laporan dan arsip terkait.

\section{Prosedur Penelitian}

\section{Penentuan Lokasi Sampling}

Plot pengamatan dipilih di tiga tipe ekosistem yang ada di Hutan Pendidikan Gunung Walat, yakni ekosistem agathis (Agathis loranthifolia), pinus (Pinus merkusii), dan puspa (Schima walichii). Pemilihan plot sampling ditentukan secara purposif, yakni plot dipilih di bawah tegakan yang memiliki tutupan tajuk yang tergolong padat dan lapisan serasah yang tergolong tebal menurut pengamatan visual peneliti. Plot sampling sejumlah 4 plot dibuat di masing-masing ekosistem. Tiap plot dibuat dalam bentuk persegi dengan luas 40x40 cm, Plot yang telah dibuat ditandai menggunakan patok kayu sebagai penandanya. Plot dibatasi dengan tali rafia untuk memperjelas area penelitian. Plot yang telah ditentukan, kemudian ditandai dengan GPS untuk keperluan pemetaan lokasi dan tracking.

\section{Prosedur Pengambilan Fauna Tanah}

Prosedur pengambilan fauna tanah pada masingmasing plot dilakukan dengan cara meraup semua serasah yang ada di atas permukaan tanah plot secara cepat dan segera dimasukkan ke dalam trashbag bening. Selain serasah, tumbuhan bawah yang berada di dalam plot pengamatan dicabut dari permukaan tanah kemudian dimasukkan ke dalam trashbag bening. Setelah permukaan plot sudah dirasa bersih dari serasah, tumbuhan bawah dan fauna tanah, trashbag yang berisi serasah dan fauna tanah tersebut kemudian diikat dengan tali rafia. Trashbag diberi label dan ditandai dengan nomor plot dan keterangan sesuai lokasi pengambilan. Lapisan tanah sedalam $10 \mathrm{~cm}$ dari permukaan digali sesuai luas plot lalu dimasukkan ke dalam trashbag yang lain dan diberi label berisi keterangan nomor plot dan lokasi. Makrofauna tanah yang terdapat pada sampel tanah dan serasah yang terambil dikumpulkan dengan hand sorting method menggunakan pinset. Makrofauna tanah yang ditemukan lalu dimasukkan ke dalam botol kecil yang berisi alkohol $70 \%$ dan diberi kode sesuai lokasi plot pengamatan. Setelah dikumpulkan dalam botol kemudian sampel difoto dan diidentifikasi di laboratorium menggunakan mikroskop digital.

\section{Pengukuran Faktor Lingkungan}

Faktor lingkungan makrofauna yang terdiri atas kerapatan dan suhu diukur sesuai dengan lokasi di masing-masing plot pengamatan. Pengukuran kerapatan tajuk menggunakan densiometer di atas titik plot pengamatan makrofauna tanah. Pengukuran kerapatan tajuk dilakukan empat kali berdasarkan arah mata angin. Suhu tanah diukur tiga kali setiap tiga menit. Pengukuran suhu tanah menggunakan menggunakan termometer tanah dengan cara memasukkan termometer tanah tersebut kurang lebih $10 \mathrm{~cm}$ dari permukaan tanah kemudian dibaca langsung angka yang tertera setelah mencapai nilai konstan.

\section{Identifikasi Makrofauna Tanah}

Seluruh makrofauna tanah yang telah dimasukkan ke dalam botol spesimen yang telah diberi label sesuai lokasi plotnya, kemudian diidentifikasi sampai tingkat famili. Identifikasi dan dokumentasi sampel makrofauna tanah menggunakan mikroskop digital. Setiap sampel yang telah didokumentasikan kemudian diberi skala ukuran dalam satuan centimeter. Identifikasi di lakukan antara lain di lab Entomologi Hutan IPB, Bogor.

\section{Tekstur Tanah dan KTK}

Penaksiran tekstur tanah dilakukan untuk mengetahui kandungan pasir, debu, dan klei yang terdapat pada sampel tanah. Tekstur tanah diamati menggunakan teknik rabaan langsung terhadap melalui permukaan tangan, serta dipirit dan dibentuk cincin. Penaksiran kadar bahan organik tanah dilakukan dengan metode kocok endap. Metode ini menggunakan sampel tanah sebanyak $50 \mathrm{cc}$ yang telah dipisahkan dari bahanbahan organik kasar, kemudian dicampur dengan akuades sebanyak $350 \mathrm{cc}$, lalu dikocok selama 5 menit hingga menjadi suspensi dalam botol air mineral $600 \mathrm{ml}$, dengan proporsi tanah dan air 1:7. Akuades dan sampel tanah yang telah tersuspensi tersebut kemudian didiamkan dan diamati pada 1 jam pertama, dan diamati kembali pada 6 jam, 12 jam dan 24 jam berikutnya.

\section{Derajat Keasaman Tanah}

Pengukuran $\mathrm{pH}$ menggunakan $\mathrm{pH}$ meter yang dicelupkan ke dalam sampel tanah dari masing-masing plot. Sampel tanah dari plot yang akan diukur dicampurkan dengan cara diaduk bersama akuades hingga tercampur dengan sempurna, kemudian diukur menggunakan $\mathrm{pH}$ meter selama 5 menit. Nilai $\mathrm{pH}$ ditentukan saat angka $\mathrm{pH}$ meter berhenti pada angka tertentu.

\section{Analisis Data}

\section{Indeks Kekayaan jenis Margalef (DMg)}

Untuk mengetahui besarnya kekayaan jenis digunakan indeks Margalef (Ludwigs \& Reynold 1988)

$$
\mathrm{DMg}=\frac{\mathrm{S}-1}{\ln (\mathrm{N})}
$$

Dimana;

$\mathrm{DMg}=$ Indeks kekayaan jenis Margalef

$\mathrm{S} \quad=$ Jumlah jenis

$\mathrm{N} \quad=$ Jumlah total individu

Berdasarkan Magurran (1988) besaran R1 < 3.5 menunjukkan kekayaan jenis tergolong rendah, $3.5<\mathrm{R} 1$ $<5,0$ menunjukkan kekayaan jenis tergolong sedang dan $\mathrm{R} 1>5.0$ menunjukkan kekayaan jenis tergolong tinggi. 


\section{Keanekaragaman Jenis (H')}

Keanekaragaman jenis adalah parameter yang sangat berguna untuk mengetahui tingkat keanekaragaman jenis.

$$
H^{\prime}=-\sum_{i=1}^{s}\left[\left(\frac{n i}{N}\right) \ln \left(\frac{n i}{N}\right)\right]
$$

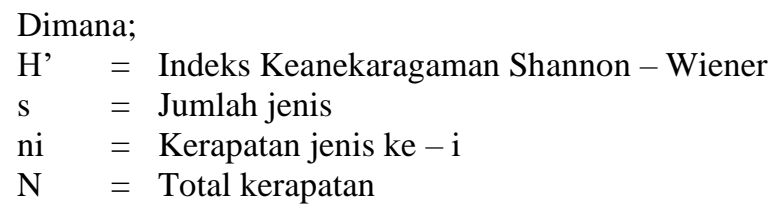

Terdapat tiga kriteria dalam analisis indeks keanekaragaman jenis yaitu jika nilai $\mathrm{H}^{\prime}<2$, maka termasuk kedalam kategori rendah, nilai $2<\mathrm{H}^{\prime}<3$, maka termasuk kedalam kategori sedang dan akan dimasukkan kedalam kategori tinggi bila H' > 3 (Magurran 1988).

\section{Kemerataan Jenis Pielou (E)}

$$
E=\frac{H^{\prime}}{\ln (S)}
$$

Dimana;

$$
\begin{array}{ll}
\mathrm{E} & =\text { Indeks kemerataan jenis } \\
\mathrm{H} & =\text { Indeks keanekaragaman jenis } \\
\mathrm{S} & =\text { Jumlah jenis }
\end{array}
$$

Berdasarkan Magurran (1988) besaran $\mathrm{E}<0.3$ menunjukkan kemerataan jenis rendah, $0.3<\mathrm{E}<0,6$ menunjukkan tingkat kemerataan jenis tergolong sedang dan $\mathrm{E}>0.6$ menunjukkan tingkat kemerataan jenis tergolong tinggi.

\section{Nilai Kesamaan Jenis (Sorensen Index)}

Koefisien kesamaan komunitas merupakan nilai yang digunakan untuk mengetahui kesamaan relatif dari komposisi jenis dan struktur antara dua komunitas yang dibandingkan (Soerianegara \& Indrawan 2002).

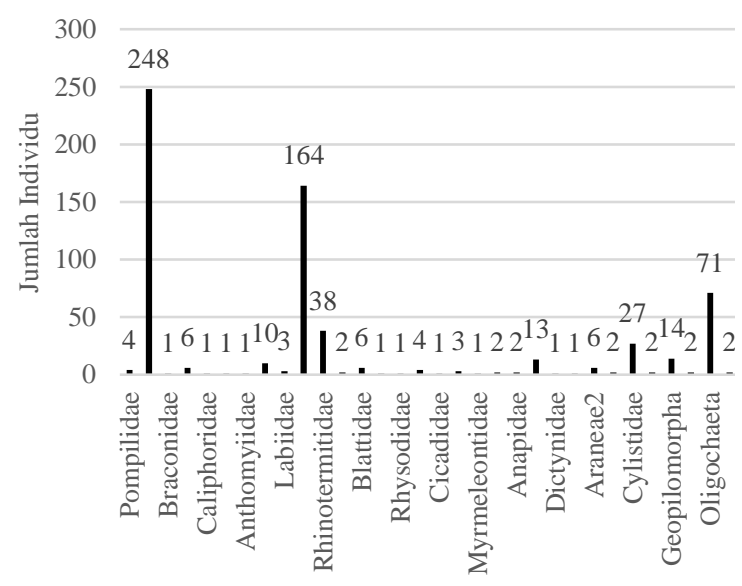

Gambar 1 Kelimpahan individu di tanah dan serasah pada seluruh plot pengamatan (Agathis, pinus, dan puspa)

$$
(I S)=\frac{2 \mathrm{~W}}{a+b}
$$

Dimana;

$$
\begin{aligned}
(\mathrm{IS})= & \text { Indeks kesaman komunitas } \\
\mathrm{W}= & \text { Jumlah nilai kuantitatif yang sama atau } \\
& \text { terendah }(\leq) \text { dari dua jenis-jenis yang } \\
& \text { terdapat dalam dua komunitas berbeda } \\
\mathrm{a}= & \text { Jumlah nilai kuantitatif dari semua jenis yang } \\
& \text { terdapat dalam komunitas pertama yang } \\
& \text { dibandingkan } \\
\mathrm{b}= & \text { Jumlah nilai kuantitatif dari semua jenis yang } \\
& \text { terdapat dalam komunitas kedua yang } \\
& \text { dibandingkan }
\end{aligned}
$$

\section{HASIL DAN PEMBAHASAN}

\section{Komposisi dan Kelimpahan Makrofauna di Tegakan Agathis, Pinus dan Puspa}

Makrofauna tanah yang ditemukan di 12 plot contoh, masing-masing berukuran $40 \times 40 \mathrm{~cm}$ pada tiga tegakan berbeda (Agathis, pinus dan puspa) di Hutan Pendidikan Gunung Walat adalah 641 individu, berasal dari lapisan tanah dan serasah (Gambar 1). Individu yang ditemukan terbagi ke dalam kelompok Insecta, Arachnida, Malacostraca, Oligochaeta, Chilopoda, Diplopoda, dan Gastropoda. Pengamatan dilakukan di lapisan tanah setebal $10 \mathrm{~cm}$ dari permukaan tanah dan lapisan serasah dengan ketebalan 3-5 cm. Pada lapisan tanah di bawah tegakan yang diamati, ditemukan 163 individu, sedangkan pada serasah ditemukan 478 individu. Jumlah kelimpahan makrofauna yang ditemukan di lapisan tanah dan serasah yang terdapat pada tegakan Agathis, pinus dan puspa secara berturut-turut sebanyak 129, 377 dan 135 individu.

\section{Kelimpahan Makrofauna Tanah yang Ditemukan pada Tegakan Agathis}

Kelimpahan makrofauna tanah yang ditemukan di 4 plot pada tegakan Agathis berjumlah 129 individu yang terdiri atas 21 kelompok (Gambar 2). Makrofuna tersebut berasal dari lapisan tanah dan serasah dari masingmasing plot. Kelimpahan di dalam lapisan serasah sebanyak 43 individu, sedangkan di dalam lapisan tanah (kedalaman $10 \mathrm{~cm}$ ) ditemukan 86 individu.

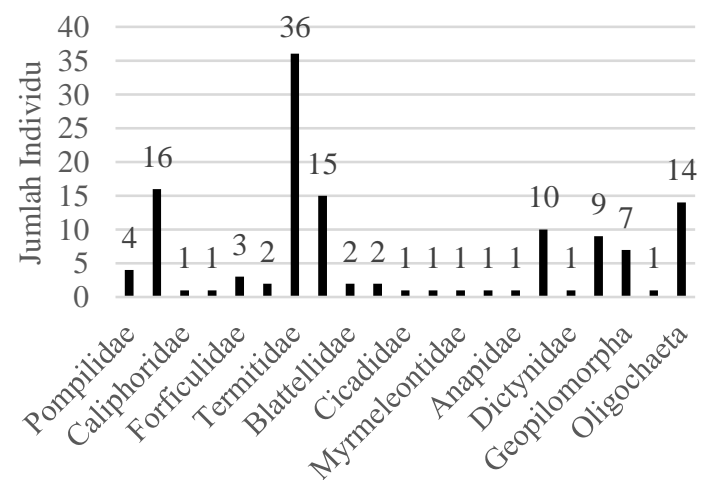

Gambar 2 Kelimpahan individu makrofauna di tanah dan serasah pada plot Agathis 


\section{Komposisi dan Kelimpahan Makrofauna Tanah di Tegakan Pinus}

Pengamatan yang dilakukan pada lapisan tanah dan serasah di 4 plot di bawah tegakan pinus, menghasilkan temuan 377 individu makrofauna dari 10 famili dari kelas Insecta, 6 famili dari ordo Araneae, dan beberapa individu dari kelompok lainnya (Gambar 3). Makrofauna yang ditemukan di bawah tegakan pinus didominasi oleh famili Formicidae, Termitidae dan sub-kelas Oligochaeta. Famili Formicidae dan Termitidae banyak ditemukan di bawah tegakan pinus. Beberapa individu yang hanya ditemukan di bawah tegakan pinus diantaranya adalah Braconidae, Figitidae, Phalacridae, Araneae1, Araneae2, dan Araneae3.

\section{Komposisi dan Kelimpahan Makrofauna Tanah di Tegakan Puspa}

Identifikasi yang dilakukan pada lapisan tanah dan serasah di 4 plot di bawah tegakan puspa menghasilkan temuan 135 makrofauna tanah. Beberapa kelompok yang paling banyak ditemukan adalah famili Formicidae (Gambar 4), Oligochatea, dan Termitidae dengan jumlah masing-masing 78, 18 dan 12 individu.

\section{Keanekaragaman Makrofauna Tanah yang} Ditemukan pada Tegakan Agathis, Pinus dan Puspa

Tegakan Agathis memiliki keragaman jenis, kekayaan jenis, dan kemerataan jenis tertinggi yaitu 2.38, 4.12 dan 0.78 .

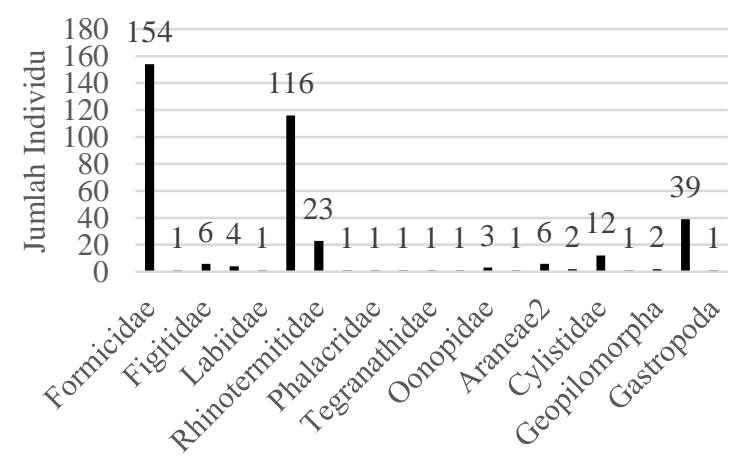

Gambar 3 Kelimpahan makrofauna di tanah dan serasah pada plot sampel tegakan pinus

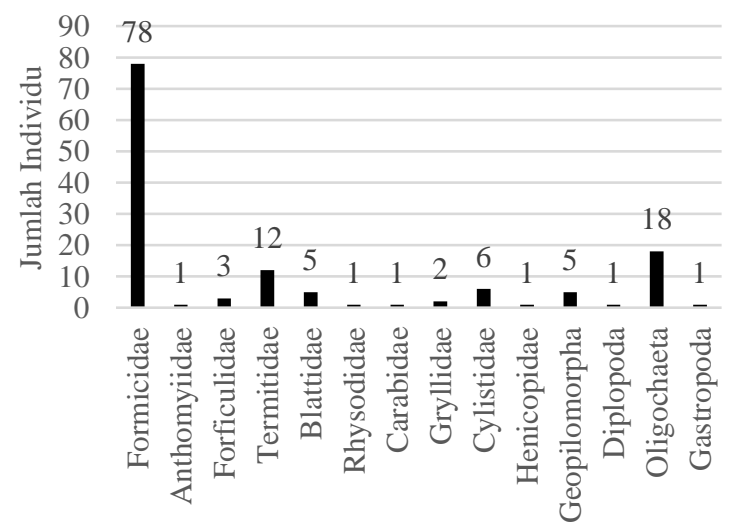

Gambar 4 Kelimpahan makrofauna di tanah dan serasah pada plot sampel tegakan puspa
Indeks Kesamaan Makrofauna Tanah di Tegakan Agathis, Pinus dan Puspa

Indeks kesamaan dari ketiga tegakan (Agathis, pinus, dan puspa) yang menunjukkan nilai terbesar terdapat pada tegakan pinus dengan puspa sebesar 0.32. Nilai kesamaan yang semakin mendekati 1 artinya kesamaan komunitas makrofauna tanah di antara ketiga tegakan tersebut tergolong tinggi.

\section{Keanekaragaman Makrofauna Tanah yang Ditemukan pada Tanah dan Serasah}

Hasil pengamatan menunjukkan bahwa berdasarkan tempat ditemukannya, biodiversitas makrofauna tanah di tegakan agathis, pinus dan puspa lebih banyak ditemukan pada lapisan tanah dibandingkan pada serasah. Nilai indeks keragaman, kekayaan dan kemerataan makrofauna tanah pada lapisan tanah yaitu sebesar 2.19, 4.32 dan 0,67 .

\section{Frekuensi Ditemukannya Makrofauna Tanah pada Tanah dan Serasah}

Makrofauna yang memiliki frekuensi dominan yang ditemukan di tanah dan serasah diantaranya adalah dari kelompok Formicidae, Oligochaeta dan Termitidae.

Tabel 1 Indeks biodiversitas makrofauna tanah antar tegakan

\begin{tabular}{lccc}
\hline Tegakan & $\mathrm{H}^{(1)}$ & $\mathrm{DMg}^{1)}$ & $\mathrm{E}^{1)}$ \\
\hline Semua & & & \\
Tegakan & 1.96 & 4.80 & 0.57 \\
Agathis & 2.38 & 4.12 & 0.78 \\
Pinus & 1.68 & 3.37 & 0.55 \\
Puspa & 1.55 & 2.65 & 0.59 \\
\hline
\end{tabular}

${ }^{1)}$ Biodiversitas makrofauna tanah di 4 plot masingmasing tegakan, tiap plot berukuran $40 \mathrm{~cm}$ x $40 \mathrm{~cm}$. $H^{\prime}$ = nilai keragaman jenis Shannon - Wiener, DMg = nilai kekayaan jenis Margalef, $\mathrm{E}=$ nilai kemerataan jenis Pielou, $\mathrm{S}=$ jumlah individu yang ditemukan.

Tabel 2 Nilai indeks kesamaan jenis antar tegakan

\begin{tabular}{|c|c|c|c|}
\hline & Agathis & Pinus & Puspa \\
\hline Agathis & & 0.25 & 0.28 \\
\hline Pinus & & & 0.32 \\
\hline Puspa & & & \\
\hline
\end{tabular}

Tabel 3 Keanekaragaman makrofauna tanah di tanah dan serasah

\begin{tabular}{lccc}
\hline Lokasi & $\mathrm{H}^{11)}$ & $\mathrm{DMg}^{1)}$ & $\mathrm{E}^{1)}$ \\
\hline Serasah & 1.79 & 3.57 & 0.57 \\
Tanah & 2.19 & 4.32 & 0.69 \\
\hline
\end{tabular}

${ }^{1)}$ Biodiversitas makrofauna tanah di 4 plot masingmasing tegakan, tiap plot berukuran $40 \mathrm{~cm} \times 40 \mathrm{~cm}$. $\mathrm{H}^{\prime}=$ nilai keragaman jenis Shannon - Wiener, $\mathrm{DMg}=$ nilai kekayaan jenis Margalef, $\mathrm{E}=$ nilai kemerataan jenis Pielou. 


\section{Perbandingan Jumlah Individu Fauna Tanah di Setiap Tegakan}

Berdasarkan jumlah individu fauna tanah, kelimpahan terbanyak ada pada ekosistem pinus sebanyak 377 individu (Tabel 4). Agathis dan pinus merupakan jumlah famili yang terbanyak ditemukan, yakni sebanyak 20 famili, disusul tegakan puspa dengan jumlah famili ditemukan sebanyak 14 famili.

\section{Hubungan antara Biodiversitas Makrofauna ddengan Faktor Lingkungan}

Beberapa faktor abiotik seperti kerapatan tajuk, suhu tanah, ketebalan serasah, pH dan Kapasitas Tukar Kation (KTK) merupakan salah satu indikator yang dapat berpengaruh terhadap kehadiran makrofauna tanah. Tegakan agathis memiliki persen kerapatan tajuk dan ketebalan serasah yang paling tinggi yakni $81.44 \%$ dan $3.25 \mathrm{~cm}$ (Tabel 5).

\section{Analisis Tekstur Tanah}

Dalam penelitian ini didapatkan hasil tekstur tanah yang bervariasi untuk tiap ekosistem. Pengamatan terhadap tekstur tanah yang dilakukan di tiga tegkaan yang (agathis, pinus, dan puspa), didapatkan tipe tekstur tanah dengan persentase clay, silt dan sand yang beragam (Tabel 2). Tipe tekstur tanah yang ditemukan dantaranya adalah Clay, Clay Loam, dan Silty Clay Loam. Tanah yang diamati untuk penaksiran tekstur tanah berasal dari Horizon A dan B pada masing-masing plot tegakan. Tekstur tanah menggambarkan perbandingan relatif antara fraksi pasir, debu dan klei,yaitu partikel tanah yang berdiameter $\leq 2 \mathrm{~mm}$.

\section{Komposisi dan Kelimpahan Makrofauna Tanah di Tegakan Agathis, Pinus dan Puspa}

Pengamatan makrofauna tanah yang dilakukan di lapisan tanah dan serasah pada 12 plot di tegakan Agathis, pinus dan puspa di Hutan Pendidikan Gunung Walat menghasilkan temuan individu makrofauna tanah sebanyak 131 individu. Kelompok makrofauna tanah yang paling banyak ditemukan berasal dari famili Formicidae (248), Termitidae (164), Oligochaeta (71). Berdasarkan ekosistem, individu makrofauna tanah paling banyak ditemukan di bawah tegakan pinus sebanyak 277 individu. Individu makrofauna tanah tersebut hidup berkoloni dan membuat sarang dalam strobilus pinus yang sudah lapuk. Kayu pinus yang sudah lapuk merupakan sumber makanan bagi rayap. Beberapa makanan yang tersedia di lantai hutan yang dijadikan

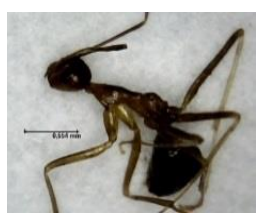

(a)

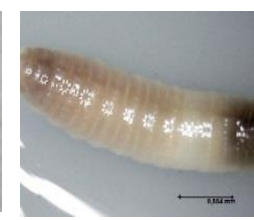

(b)

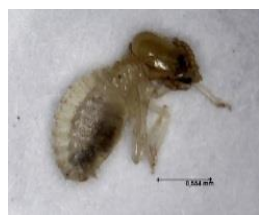

(c)
Gambar 5 Makrofauna tanah yang memilki nilai frekuensi terbesar. a) Formicidae, b) Oligochaeta, c) Termitidae. sumber makanan bagi rayap adalah kayu, lumut dan humus yang berasal dari busukan daun dan sampah kayu.

Penelitian Firmansyah (2012) di Hutan Pendidikan Gunung Walat menunjukkan bahwa Termitidae memiliki sebaran yang luas dan hampir ditemukan di seluruh tegakan yang ada. Kondisi bawah tegakan yang cukup lembab yakni berkisar antara $21-23^{\circ} \mathrm{c}$ mendukung perkembangbiakan makrofauna tanah yang dominan ditemukan di lantai hutan seperti semut dan rayap. Kondisi kanopi yang luas pada tegakan Agathis dan puspa juga menyebabkan kelembaban meningkat dan intensitas matahari rendah sehingga kondisi di bawah kanopi menjadi relatif basah dan dingin (suhu rendah) (Setyawan 2000).

Termitidae, Formicidae, Rhinotermitidae adalah famili yang mendominasi di plot contoh tegakan Agathis dengan jumlah masing-masing 36, 15, dan 14 individu. Oligochaeta merupakan kelompok non-insekta yang paling banyak ditemukan di plot tegakan Agathis, dengan jumlah kelimpahan 14 individu. Meski banyak ditemukan di dalam lapisan tanah, Oligochaeta juga ditemukan pada lapisan serasah. Hal tersebut dapat terjadi karena kondisi lapisan serasah yang lembab dan basah akibat hujan yang turun sehari sebelum waktu pengamatan. Cacing tanah sangat berguna untuk memacu proses mineralisasi dan humifikasi bahan organik secara langsung maupun tidak langsung (Arief 2001). Berdasarkan hasil pengamatan, makrofauna yang mendominasi di bawah tegakan pinus berasal dari famili Formicidae, Termitidae dan kelas Oligochaeta. Formicidae dan Termitidae banyak ditemukan di dalam tanah di bawah tegakan agathis dan membentuk koloni serta melapukkan kayu tua yang tertimbun di dalam tanah. Beberapa individu yang tidak ditemukan di tegakan selain pinus diantaranya adalah Braconidae, Figitidae, Phalacridae, Araneae1, Araneae3, dan Araneae4.

Tabel 4 Perbandingan jumlah individu ditemukan di tiap plot tegakan

\begin{tabular}{cccc}
\hline & Agathis & Pinus & Puspa \\
\hline Tanah $^{1)}$ & 86 & 56 & 21 \\
Serasah $^{2)}$ & 34 & 321 & 114 \\
Total & 120 & 377 & 135 \\
\hline
\end{tabular}

$1=$ tebal tanah $10 \mathrm{~cm} .2=$ tebal serasah $3-5 \mathrm{~cm}$.

Tabel 5 Faktor abiotik di tegakan agathis, pinus dan puspa

\begin{tabular}{|c|c|c|c|}
\hline \multicolumn{4}{|c|}{ Agathi } \\
\hline Faktor Abiotik & $\mathrm{s}$ & Puspa & Pinus \\
\hline Kerapatan tajuk $^{1)}$ & 81.44 & 75.75 & 72.88 \\
\hline Suhu tanah ${ }^{2)}$ & 22.00 & 21.50 & 22.0 \\
\hline Ketebalan serasah ${ }^{3)}$ & 3.25 & 2.12 & 2.73 \\
\hline $\mathrm{pH}^{3)}$ & 6.10 & 6.25 & 5.10 \\
\hline $\begin{array}{l}\text { KTK (uji kocok } \\
\text { endap) }\end{array}$ & Tinggi & Tinggi & Tinggi \\
\hline
\end{tabular}

1) dalam persen 2) suhu rata-rata tiap plot dalam tegakan 3) ketebalan serasah rata-rata dari tiap plot dalam tegakan 4) Suspensi tanah dan air jernih dalam waktu $<1$ jam $=$ rendah, $1-24$ jam $=$ sedang, $>24$ jam $=$ tinggi 
Identifikasi yang dilakukan pada tegakan puspa menghasilkan temuan makrofauna tanah sebanyak 139 individu, paling sedikit di antara tegakan yang lain. Fauna tanah yang ditemukan berasal dari 7 kelas, ordo dan 16 famili. Dari temuan tersebut, famili yang paling banyak ditemukan adalah Formicidae dengan jumlah 36 individu. Tegakan puspa merupakan tegakan dengan kondisi paling lembab di antara kedua tegakan lainnya. Hal tersebut berpengaruh terhadap individu makrofauna yang ditemukan. Perbedaan yang signifikan tersebut dapat terlihat dari jumlah individu dari kelas Oligochaeta yang ditemukan di plot tegakan ini yakni sejumlah 18 individu, terbanyak setelah famili Formicidae.

Formicidae dan Termitidae ditemukan dalam jumlah banyak di tumpukan serasah maupun galian lapisan tanah $(0-10 \mathrm{~cm})$. Keduanya ditemukan baik secara individu maupun berkoloni di sarang seperti kayu lapuk dan strobilus. Hal tersebut dibuktikan dengan tingginya jumlah individu semut dan rayap yang ditemukan dalam jumlah banyak di bawah tegakan pinus (95 individu). Rayap dan semut merupakan famili yang berperan untuk membantu proses dekomposisi bahan organik tanah sehingga memudahkan mikrobia melakukan proses perombakan secara kimia. Proses dekomposisi di dalam tanah tidak akan mampu berjalan cepat bila tidak ditunjang oleh makrofauna tanah (Arief 2001).

Perbedaan karakteristik pada tegakan Agathis, pinus dan puspa mengakibatkan individu yang ditemukan berbeda pada tiap tegakan. Hal tersebut disebabkan karena pada saat pengamatan ditemukan sarang koloni individu seperti Formicidae yang membuat lorong di dalam lapisan tanah dan Termitidae pada strobilus yang ada di lantai tegakan pinus. Kondisi permukaan tanah dan lapisan serasah yang cukup lembab menyebabakan individu tersebut lebih banyak beraktivitas dalam sarang daripada berinteraksi di luar secara terbuka, sehingga lebih mudah ditemukan dalam bentuk koloni.

Secara khusus pada tegakan Agathis ditemukan beberapa individu dari famili tertentu yang tidak ditemukan pada tegakan lain. Beberapa famili tersebut diantaranya adalah Pompilidae, Caliphoridae, Culicidae, Blattelidae, Cicadidae, Myrmeleontidae, Anapidae dan Dyctinidae. Daun-daun Agathis memiliki luas permukaan yang lebih lebar dibandingkan puspa dan pinus membentuk lapisan serasah yang lebih tebal sehingga menunjjang kehidupan makrofauna tanah. Selain pada Agathis, Individu yang hanya ditemukan pada tegakan pinus berasal dari ordo Insecta seperti famili Braconidae, Figitidae, Phalacridae, dan famili dari ordo Araneae seperti Aranae1, Araneae3, Araneae4. Famili yang hanya ditemukan di tegakan puspa yaitu Anthomiiydae dan Rhysodidae.

Analisis keragaman menggunakan indeks ShannonWiener menunjukkan bahwa tegakan agathis memiliki nilai keanekaragaman tertinggi yaitu sebesar $\mathrm{H}^{\prime}=0.013$. Tegakan Agathis memiliki nilai keragaman tertinggi dibandingkan dengan dua tipe tegakan lainnya, yakni pinus $\left(\mathrm{H}^{\prime}=.0129\right)$ dan puspa $\left(\mathrm{H}^{\prime}=0.013\right)$. Tegakan Agathis juga memiliki indeks kemerataan tertinggi yaitu 0.7515 , tertinggi disbanding pinus $(0.5501)$ dan puspa (0.5867). Hal tersebut didukung dengan kondisi tegakan Agathis yang memiliki tingkat kerapatan tajuk dan kondisi serasah yang lembab sehingga cocok untuk tempat hidup makrofauna tanah.

Nilai E berkisar antara $0-1$. Nilai yang mendekati 0 menunjukkan bahwa terdapat spesies yang dominan dalam komunitas. Jika nilai mendekati 1 menunjukkan seluruh spesies memiliki tingkat kemerataan spesies yang hampir sama atau tidak terdapat dominasi suatu spesies tertentu. Berbeda dengan nilai keragaman, tegakan pinus memiliki nilai indeks kekayaan tertinggi yakni sebesar 3.3714, diikuti oleh Agathis (3.3418) dan puspa (2.6502). Meskipun kondisi ekosistem pada tegakan pinus cenderung kurang mendukung seperti kerapatan tajuk $(72.88 \%)$ yang lebih rendah diantara dua tegakan lainnya, namun hal tersebut tidak berpengaruh terhadap kelimpahan makrofauna yang terdapat pada tegakan pinus. Hal ini berlawanan dengan penelitian Sugiyarto (2002) yang menunjukkan bahwa kerapatan tajuk berkorelasi negatif dengan tingkat penetrasi cahaya matahari yang masuk ke lantai hutan.

Tanah merupakan salah satu faktor yang paling penting dalam mempengaruhi perkembangbiakan organisme tanah. Tanah menyediakan bahan makanan yang dibutuhkan makrofauna tanah sekaligus tempat berinteraksi dengan individu lain dalam ekosistem. Selain tanah sebagai faktor fisik utama, beberapa faktor yang mmepengaruhi komposisi dan kelimpahan makrofauna tanah adalah suhu, kerapatan tajuk dan $\mathrm{pH}$ tanah. Perbedaan suhu dan kelembaban udara dari masing-masing ekosistem dapat terjadi karena perbedaan intensitas cahaya matahari.

Hal tersebut dipengaruhi oleh kerapatan tajuk yang diduga berpengaruh pula terhadap kelembaban udara di bawah tegakan. Suhu tanah akan menentukan tingkat dekomposisi material organik tanah. Secara tidak langsung terdapat hubungan kepadatan organisme tanah dan suhu, bila dekomposisi material tanah lebih cepat maka vegetasi lebih subur dan mengundang serangga untuk datang. Suhu tanah pada lokasi pengamatan berkisar $21,5-22^{\circ} \mathrm{C}$. Menurut Solihin (2000), kisaran suhu tersebut cocok untuk perkembangbiakan populasi makrofauna tanah terutama yang mendominasi di seluruh tegakan seperti rayap. Rayap dapat berkembangbiak secara optimal pada kisaran suhu $19,7-23^{\circ} \mathrm{C}$.

Keberadaan fauna tanah juga didukung oleh derajat keasaman tanah yang cocok. Derajat keasaman tanah yang terukur dari tiap tegakan berkisar antara 5-6,9 $(\mathrm{pH}$ air $=7,2$ ). Hal tersebut sesuai dengan penelitian Wulandari (2013) yang menyatakan bahwa $\mathrm{pH}$ tanah di Hutan Pendidikan Gunung Walat termasuk kategori netral sehingga mendukung perkembangbiakan jamur dan pengurai. Menurut Rahmawaty (2004), fauna tanah dapat hidup di kondisi tanah dengan derajat keasaman asam ataupun basa tergantung dari jenisnya.

Ketebalan serasah berpengaruh terhadap jumlah serasah yang terdekomposisi, semakin tebal serasah maka akan semakin banyak bahan organik yang dihasilkan (Syaufina et. al. 2007). Tebal serasah pada seluruh lokasi pengamatan yang tersebar di Hutan Pendidikan Gunung Walat berkisar antara 2-3,3 cm. Lapisan serasah berfungsi sebagai tempat hidup berbagai macam makrofauna tanah seperti Arthropoda.

Suhu tanah merupakan salah satu faktor fisika tanah yang sangat menentukan kehadiran dan kelimpahan organisme tanah, dengan demikian suhu tanah akan 
menentukan tingkat dekomposisi material organik tanah. Fluktuasi suhu tanah lebih rendah dari suhu udara, dan suhu tanah sangat tergantung dari suhu udara. Suhu tanah lapisan atas mengalami fluktuasi dalam satu hari satu malam dan tergantung musim. Fluktuasi itu juga tergantung pada keadaan cuaca, topografi daerah dan keadaan tanah (Suin 2006).

Temperatur sangat mempengaruhi aktivitas mikrobial tanah. Laju optimum aktivitas biota tanah yang umumnya terjadi pada suhu $18-30^{\circ} \mathrm{C}$. (Hanafiah 2007). Keadaan iklim daerah dan berbagai tanaman yang tumbuh pada tanahnya serta berlimpahnya mikroorganisme yang mendiami suatu daerah sangat mempengaruhi keanekaragaman relatif populasi mikroorganisme. Faktor-faktor lain yang mempunyai pengaruh terhadap keanekaragaman relatif populasi mikroorganisme adalah reaksi yang berlangsung di dalam tanah dan kelembaban tanah.

\section{Analisis Tekstur Tanah}

Analisis tekstur tanah digunakan untuk mengetahui kualitas tanah terutama jika dilihat secara fisik. Informasi mengenai persentase debu, pasir dan klei menentukan tingkat kemampuan tanah tersebut dalam mempertahankan air yang dihubungkan dengan kelembaban tanah sebagai tempat hidup dan penyedia bahan makanan bagi makrofauna tanah. Secara umum tipe tekstur tanah yang diperoleh dari beberapa lokasi yang diamati, merujuk pada dua tipe tekstur yakni Silty Clay Loam dan Clay. Tanah sebagai tempat hidup makrofauna menyediakan berbagai asupan nutrisi berupa bahan organik yang dibutuhkan untuk kelangsungan hidup di dalam maupun permukaannya.

\section{SIMPULAN DAN SARAN}

\section{Simpulan}

Makrofauna yang ditemukan pada tegakan Agathis, Pinus dan Puspa di Hutan Pendidikan Gunung Walat didominasi dari famili Formicidae (248), Termitidae (164), dan sub-klas Oligochaeta (71). Tegakan pinus memliki jumlah makrofauna terbanyak yaitu 377 individu. Kelimpahan yang ditemukan pada lapisan serasah $(3-5 \mathrm{~cm})$ lebih tinggi dibandingkan pada lapisan tanah $(0-10 \mathrm{~cm})$. Tingkat keragaman makrofauna tanah tertinggi ditemukan pada tegakan Agathis. Tutupan tajuk yang rapat berpengaruh terhadap keragaman jenis makrofauna yang berada di bawahnya. Jumlah kelimpahan makrofauna pada suatu tegakan tidak selalu berkorelasi positif terhadap tingkat keragaman di tegakan tersebut.

\section{Saran}

Penelitian selanjutnya dibutuhkan untuk mengetahui kelimpahan dan keragaman makrofauna tanah yang ada di Hutan Pendidikan Gunung Walat menggunakan metode pengumpulan sampel selain hand sorting method, serta melakukan analisis tanah secara kimia untuk mengetahui unsur dan pengaruh terhadap makrofauna yang berinteraksi di dalam tanah.

\section{DAFTAR PUSTAKA}

Arief A. 2001. Hutan \& Kehutanan. Jakarta (ID) : Penerbit Kanisius.

Arsyad S. 2006. Konservasi Tanah dan Air. Bogor (ID): IPB Press.

Borror DJ, Triplehorn CA, Johnson NF. (1996). Pengenalan pelajaran serangga Edisi ke-6. Partosoedjono S, penerjemah. Yogyakarta (ID): Gajahmada Univ Pr. Terjemahan dari: An introduction to the study of insect.

Firmansyah, A. 2012. Keanekaragaman rayap tanah di Hutan Pendidikan Gunung Walat, Sukabumi [skripsi]. Bogor [ID]: Institut Pertanian Bogor.

Hanafiah KA, Napoleon A, Ghofar N. 2007. Biologi Tanah. Jakarta (ID): PT. Raja Grafindo Persada.

Setyawan DA. 2000. Tumbuhan epifit pada tegakan pohon Schiima Wallichii (D.C.) Khorth. di Gunung Lawu [skripsi]. Surakarta: Jurusan Biologi Fakultas MIPA UNS Surakarta.

Sugiyarto, Efendi M, Mahajoeno E, Sugiti Y, Handayanto E, Agustina L. 2007. Preferensi berbagai jenis makrofauna tanah terhadap sisa bahan organik tanaman pada intesitas cahaya yang berbeda. Biodiversitas 7(4) : 96-100.

Suin NM. 2006. Ekologi Hewan Tanah. Jakarta (ID): Bumi Aksara.

Solihin. 2000. Keanekaragaman binatang tanah pada berbagai tegakan hutan [skripsi]. Bogor (ID): Institut Pertanian Bogor.

Rahmawaty. 2004. Studi Keanekaragaman mesofauna tanah di kawasan Hutan Wisata Alam Sibolangit (Desa Sibolangit, Kecamatan Sibolangit, Kabupaten Daerah Tingkat II Deli Serdang, Propinsi Sumatera Utara) [skripsi]. Medan (ID): Institut Pertanian Bogor.

Syaufina L, Haneda NF, Buliyansih A. 2007. Keanekaragaman arthropoda tanah di Hutan Pendidikan Gunung Walat. Media Konservasi 7(2):57-66.

Wibowo C, Wulandari SD. 2014. Keanekaragaman insekta tanah pada berbagai tipe tegakan di Hutan Pendidikan Gunung Walat dan hubungannya dengan peubah lingkungan. Jurnal Silvikultur Tropika 5(1): 33-42.

Wulandari SD. 2013. Keanekaragaman insekta tanah pada berbagai tipe tegakan Hutan Pendidikan Gunung Walat, Kabupaten Sukabumi, Jawa Barat [Skripsi]. Bogor (ID): Institut Pertanian Bogor. 